of the kidney will render puncture more accurate in future. In our remaining cases puncture was able to confirm the presence of multiple cysts in two cases (one unilateral), to exclude cystic disease in one case, and to confirm the presence of hydronephrosis in one. In the latter case a period of drainage through a tube introduced percutaneously improved the child's condition sufficiently to render him fit for operation. Our experience therefore indicates that in suitable cases diagnostic puncture is a simple method of providing information which may otherwise be difficult to obtain.

We are grateful to our colleagues Drs. Philip Evans, Michael Joseph, and Leo Stimmler for allowing us to report these cases who were admitted under their care.

\section{References}

Lalli, A. F. (1969). Pediatrics, 44, 1016.

Lindblom, K. (1946). Acta Radiologica, 27, 66.

Ogg, C. S., Saxton, H. M., and Cameron, J. S. (1969). British Medical fournal, 4, 657 .

Philp, T., Cockburn, F., and Anderson, J. M. (1973). Clinical Radiology,

Renert, W. A., Berdon, W. E., Baker, D. H., and Rose, J. S. (1972). Radio$\log y, 105,97$

Saxton, H. M., Ogg, C. S., and Cameron, J. S. (1972). British Medical Bulletin, 28, 210

Sherwood, T., and Stevenson, J. J. (1971). Clinical Radiology, 22, 180.

Sherwood, T., and Stevenson, J. J. (1972). British fournal of Radiology, 45, 812.

Stern, L., Fletcher, B. B., Dunbar, J. S., Levant, M. N., and Fawcett, J. S. (1972). American fournal of Roentgenology, 116, 785.

Weens, H. S., and Florence, T. J. (1954). Fournal of Urology, 72, 589.

Wickbom, I. (1954). Acta Radiologica, 41, 505.

\title{
Regular Decline in Physical Working Capacity with Age
}

\author{
L. E. BÖTTIGER
}

British Medical fournal, 1973, 3, 270-271

\section{Summary}

Analysis of the results of two cross country races, one on foot and one on skis, in which nearly 10,000 men competed showed that performance is very closely matched with age. There is a decrease of $5-10 \%$ in the performance every 10 years from optimum age for the event. This optimum varies for different types of physical activity. Studies in a small group of women showed similar variations.

\section{Introduction}

Information about the value of regular physical activity in Sweden has led to mass participation in various athletic activities such as cross-country running and skiing. In some of the events as many as 10,000 entrants-that is, one Swedish man out of every 500-have been registered. Most of the participants are not professional athletes, but in fact constitute a cross-section of the population with regard to age, occupation, education, etc.

This development is largely a positive one, but of course there are also certain risks involved, mainly that people overestimate their physical capacity, which may have serious medical consequences. It is thus important to study the alteration of physical working capacity with age. This has been done for the Vasa ski race (Böttiger, 1971). A new study of a cross-country running event, however, made the combined results more significant and worthy of a further report.

\section{Material}

The Lidingö cross-country race is run over a distance of $30 \mathrm{~km}$ (19 miles). In 1972 about 2,200 male runners were registered as entrants, 1,911 of whom completed the race. Ninety women ran a shorter distance ( $16 \mathrm{~km}, 10$ miles).

The Vasa cross-country ski race over a distance of $87 \mathrm{~km}$ \footnotetext{
Department of Internal Medicine, Karolinska Hospital, Stockholm
Sweden

L. E. BÖTTIGER, M.D., Professor of Medicine
}

(54 miles) has been previously described (Böttiger, 1971). In 1970 7,625 male skiers completed the race-women are not allowed to participate.

In the present study running time and age were recorded for all participants in the Lidingö race, and conventional statistical methods have been used.

\section{Results}

The running times in relation to age are shown in figs. 1 and 2 , and statistical variables and age distribution are given in the table. The results within each age group were found to be essentially normally distributed, with a slight tendency towards tailing on the side of the longest running times.

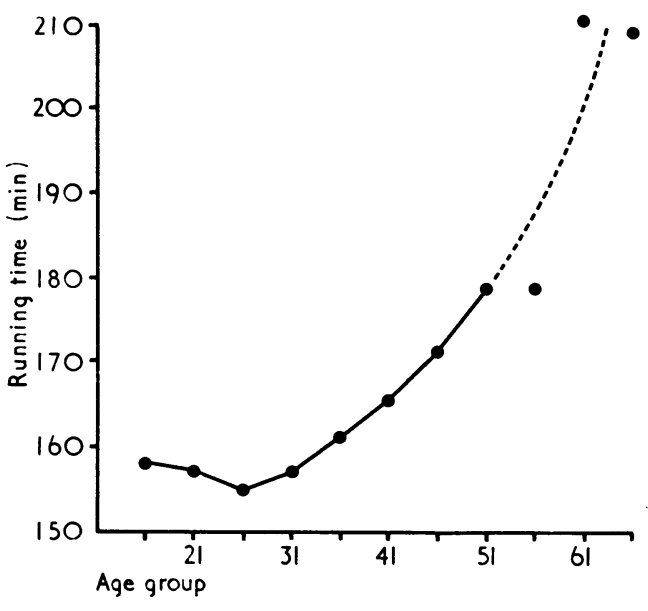

FIG. 1-Running times in relation to age. Mean times of each five-year group of men.

The relative results in different age groups for men, calculated as a percentage of the best results, are given in fig. 3 for the Vasa as well as for the Lidingö race.

It is evident that the age-bound variation in physical performing capacity is a regular phenomenon. Though the best results in the two types of activity are obtained at a some- 
what different age the age-variation curves are strictly parallel. The decrease with age from the time of maximum performance for men as well as for women is in the order of $5-10 \%$ every 10 years.

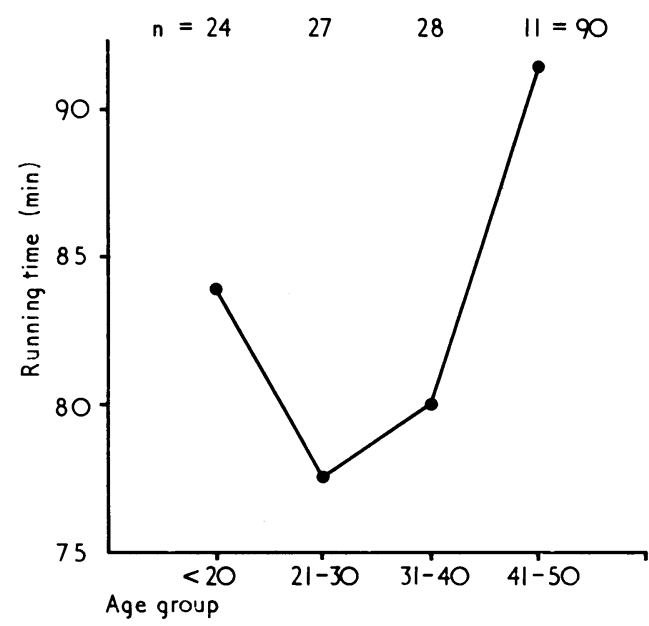

FIG. 2-Running times in relation to age. Mean times of each 10-year group of women.

Results of Lidingö Cross-Country Race in Relation to Age

\begin{tabular}{|c|c|c|c|c|}
\hline \multirow{2}{*}{$\begin{array}{c}\text { Age Group } \\
\text { (Years) }\end{array}$} & \multirow{2}{*}{$\begin{array}{c}\text { No. of } \\
\text { Competitors }\end{array}$} & \multicolumn{3}{|c|}{ Running Times (Minutes) } \\
\hline & & Mean & S.D. & S.E. of Mean \\
\hline \multicolumn{5}{|c|}{ Males $(30 \mathrm{~km})$} \\
\hline $\begin{array}{l}11-15 \\
16-20 \\
21-25 \\
26-30 \\
31-35 \\
36-40 \\
41-45 \\
46-50 \\
51-55 \\
56-60 \\
61-65 \\
66-70\end{array}$ & $\begin{array}{r}1 \\
23 \\
299 \\
474 \\
385 \\
251 \\
224 \\
165 \\
59 \\
21 \\
5 \\
4\end{array}$ & $\begin{array}{l}158 \cdot 4 \\
157 \cdot 2 \\
154 \cdot 7 \\
157 \cdot 3 \\
161 \cdot 4 \\
165 \cdot 3 \\
170 \cdot 8 \\
178 \cdot 4 \\
177 \cdot 7 \\
211 \cdot 4 \\
206.0\end{array}$ & $\begin{array}{l}25.9 \\
30 \cdot 6 \\
29 \cdot 1 \\
27.6 \\
25.9 \\
24 \cdot 0 \\
25.9 \\
24 \cdot 5 \\
24 \cdot 8 \\
63.1 \\
29.7\end{array}$ & $\begin{array}{r}5.4 \\
1.8 \\
1.3 \\
1.4 \\
1.6 \\
1.6 \\
1.7 \\
3.1 \\
5.4 \\
28.2 \\
14.8\end{array}$ \\
\hline \multicolumn{5}{|c|}{ Females (16 km) } \\
\hline $\begin{array}{r}<20 \\
21-30 \\
31-40 \\
41-50\end{array}$ & $\begin{array}{l}24 \\
27 \\
28 \\
11\end{array}$ & $\begin{array}{l}84 \cdot 0 \\
77 \cdot 3 \\
80 \cdot 0 \\
91 \cdot 5\end{array}$ & $\begin{array}{r}14.2 \\
9.9 \\
9.7 \\
9.6\end{array}$ & $\begin{array}{l}2 \cdot 9 \\
1.9 \\
1 \cdot 8 \\
2 \cdot 9\end{array}$ \\
\hline
\end{tabular}

\section{Discussion}

The similarity, not to say identity, of the two curves in fig. 3 is striking. It indicates that in population samples as large as these $(2,000-7,000)$ individual variations disappear and the results attain a general and biological significance. The variations with age are identical in the two curves and correspond to a decrease in physical working capacity from the time of maximum performance with a $5-10 \%$ decline for each 10 -year period. The results should be of interest and importance even outside athletic circles. For example, it has been shown that the age-bound variations in the results in the Vasa ski race are closely parallel to the same age-bound variations in the piece-rate earnings of Swedish lumberjacks (Böttiger, 1971).

Even if physical working capacity for large population groups is no longer the important and limiting factor in daily life, there

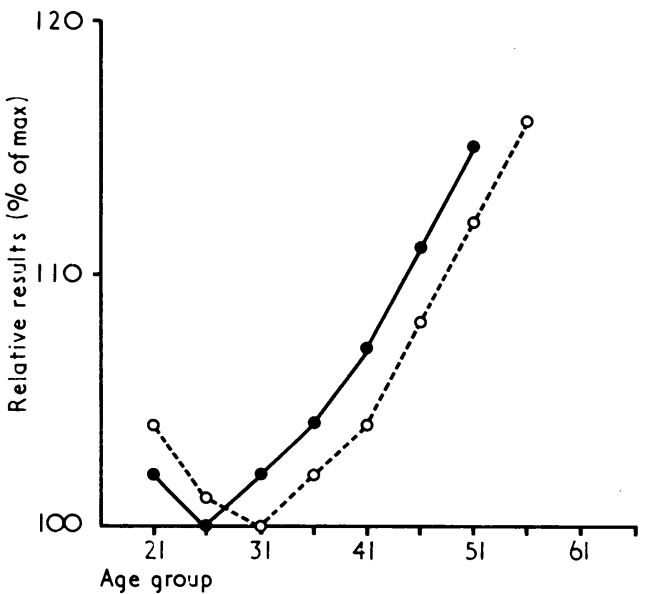

FIG. 3-Relative results for men, given as per cent. of maximum performance, for the Vasa ski race ( -0$)$ and for the Lidingö race (

are results that show that an individual in ordinary physical work will choose a work load that in a regular way corresponds to his maximum oxygen uptake-or "working capacity"-as determined in the laboratory. In building workers this level has been shown to be $40 \%$ (Asstrand, 1967). Thus, it is fair to assume that a good result in athletic competitions would also indicate good working capacity in everyday work.

The two curves show a parallel displacement of about five years, indicating that the maximal performing capacity for the more strenuous-and longer-ski race is obtained at a somewhat later age than for the shorter running event.

As shown previously (Böttiger, 1971), the curve for maximal oxygen uptake is largely parallel to the two performance curves, but with its maximum at an even younger age-between 15-20 years (Åstrand, 1960). Factors other than the decline in maximal oxygen uptake capacity clearly are also of importance. Interest has lately been directed towards the muscles themselves and especially to their triglyceride content. This has been shown to increase with age, regardless of serum triglyceride concentration (Fröberg, 1973). In a preliminary study it has also been shown that physical training may counteract the age effect (Böttiger and Fröberg, 1973), and, finally, that there exists a negative correlation between the total work load performed on a bicycle ergometer and the muscle triglyceride content $(r=0.53$, $P<0.01)$ - that is, the higher the triglyceride content the lower the physical performing capacity (Carlson et al., 1971). These findings, however, have to be extended before their possible significance for the general age-bound decrease in physical working capacity can be ascertained.

Requests for reprints should be addressed to: Professor L. E. Böttiger, Läkemedelsavdelningen (Department of Drugs), Fack, S-10401 Stockholm, Sweden.

\section{References}

Åstrand, I. (1967). Ergonomics, 10, 293.

Astrand, P. O. (1960). Experimental Studies of Physical Working Capacity in Relation to Sex and Age. Copenhagen, Munksgaard.

Böttiger, L. E., and Fröberg, S. O. (1973), In preparation.

Böttiger, L. E., and Fröberg, S. O. (1973), In preparation.

Carlson, L. A., Ekelund, L. G., and Fröberg, S. O. (1971). European fournal of Clinical Investigation, 1, 248.

Fröberg, S. O. (1973). Acta Medica Scandinavica. In press. 